\title{
NOTES ON NORTH AMERICAN NITIDULIDAE: POCADIUS
}

\author{
By C. T. PARsons. \\ Biological Laboratories, Harvard University
}

In addition to the four species of Pocadius treated below there are known seven from Asia, two from Brazil, and one each from Argentina, Cuba, Europe, and Africa.

Since helvolus extends southward into Mexico and Cuba, and basalis and niger n. sp. are found in Arizona and New Mexico, these species are probably of Neotropical origin. The California fulvipennis, although described from "Mexico," is related to the European ferrugineus in the shape and punctation of the elytra, profile of the prosternum, and characters of the female genitalia and is probably of Asiatic origin.

Helvolus, niger n. sp. and basalis are rather closely related and quite distinct from fulvipennis. In the use of the following key, figures 1-4 should be consulted.

1. Prosternum in profile strongly arcuate...fulvipennis Er. Prosternum in profile moderately arcuate or nearly plane 2.

2. Prosternum behind the coxa plane, not deflexed basalis Schaef.

Prosternum behind the coxa more or less deflexed........3.

3. Pronotum black with hind angles obtusely rounded niger $\mathrm{n}$. sp.

Pronotum testaceous to piceous with hind angles acutely rounded helvolus Er.

\section{Pocadius fulvipennis Erichson}

Pocadius fulvipennis Erichson, 1843, in Germar, Zeitschr. Ent., 4 : 319. 
Pocadius dorsalis Horn, 1879, Trans. Amer. Ent. Soc., 7 : 311.

The color varies from black with a red basal spot on each elytron to testaceous. This species was described from "Mexico.". Dorsalis was based on the black form. In the United States it is found only in California ranging from Los Angeles Co. to an altitude of 2,500 feet, Carrville, Trinity Co. The Carrville specimens are dated June 19. In Mr. H. C. Fall's collection is a specimen collected on March 17 in Marin Co. from the "puff ball Lycoperdon giganteum."
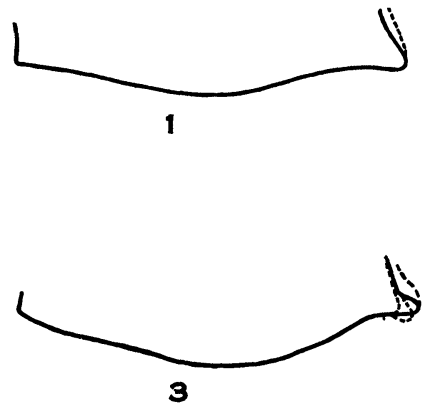
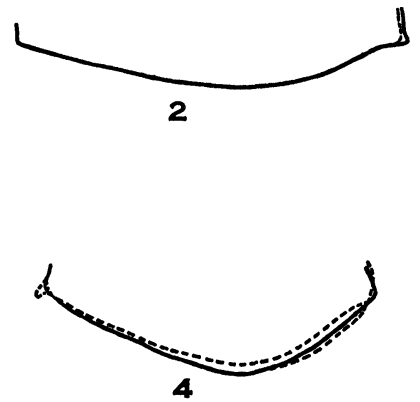

Fig. 1. Profile of the prosternum in Pocadius. The dotted lines show the extent of variation. 1, P. basalis, holotype in solid line; 2, $P$. niger n. sp., holotype in solid line; $3, P$. helvolus, the usual form in solid line; $4, P$. fulvipennis, lectotype of $P$. dorsalis in solid line. This is the usual form; the least arcuate outline in Fig. 4 is identical with that of the European P. ferrugineus.

\section{Pocadius helvolus Erichson}

Pocadius helvolus Erichson, 1843, in Germar, Zeitschr. Ent., 4: 320 .

Pocadius breviusculus Reitter, 1876, Stettiner Ent. Zeit, $37: 318$.

Pocadius ferrugineus Chevr., 1863, Am. Soc. Ent. France (4) 3:604 (in error).

Pocadius infuscatus Reitter, 1874, Syst. Eintheil. Nitid., p.

94. 
Pocadius limbatus Reitter, 1874, Syst. Eintheil. Nitid., p. 95.

Helvolus varies considerably in size, punctation, and color, ranging from pale testaceous to dark rufo-testaceous with the elytra black except at base. As a result Reitter has named three forms. In the Horn collection there are specimens compared with Reitter's types, and since these variations have no geographical significance they had better remain synonyms as Horn placed them.

Described from "North America" helvolus ranges from Stamford, Connecticut and West Point, New York to Thomasville, Georgia west to "B. C." (H. C. Fall coll.), "Montana" (Sharp), Nebraska, Kansas, eastern Texas (Columbus and Houston), and northwards to Aweme, Manitoba. The dates run from June to September. Specimens from New Jersey received from Mr. C. A. Frost were taken in Lycoperdon giganteum. It is recorded from Cuba by Chevrolat (under ferrugineus) and by Reitter (as infuscatus and limbatus). Sharp recorded this species from Mexico (Durango and Guanajuata).

\section{Pocadius niger new species}

Fig. 1 (2), Fig. 2 (7)

Broadly oval, robust; head and pronotum black, elsewhere dark piceous except for a somewhat triangular reddish brown spot on each elytron. Head coarsely irregularly punctured; front transversely impressed. Thorax as wide as long, narrowed in front; apex rather strongly emarginate; base arcuate, and feebly sinuate at each side. The sides of the thorax moderately and evenly arcuate, narrowly inflexed; hind angles obtusely rounded; disc convex, coarsely irregularly punctured. Sides of elytra feebly arcuate, apex truncately arcuate, sutural angle feebly dentiform; disc convex, with ten rows of distinct punctures (obscure near the sutural margin in the Arizona specimens); the intervals flat, irregularly biseriately punctulate, each puncture with a fulvous hair. Body beneath coarsely sparsely punctured. Length 4.3-3.2 mm., width 2.2-1.9 $\mathrm{mm}$. 
Described from thirteen specimens collected by Barber and Schwartz on June 8 at Las Vegas Hot Springs, New Mexico. The male holotype, allotype, and 6 paratypes in the U.S.N.M., one pair of paratypes in the Mus. Comp. Zoöl. and one paratype each in the collections of H. C. Fall and the writer. Also one paratype from the Pinal Mts., Arizona and one paratype from the Sierra Ancha Mts., Arizona in the collection of H. C. Fall.
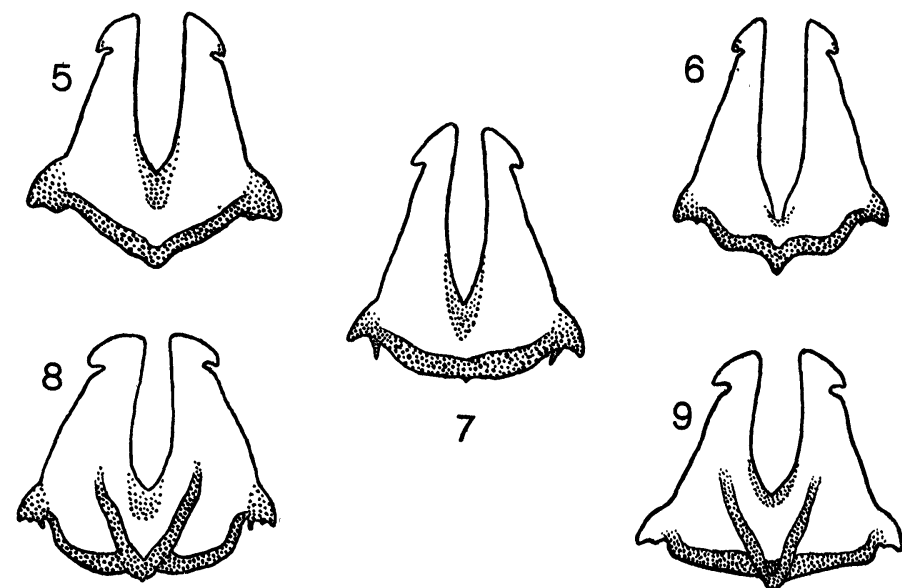

Fig. 2. Ventral views of the coxites of the female genitalia in Pocadius. 5, P. basalis Schaeffer (topotype); 6, P. helvolus Er.; 7, $P$. niger n. sp. (paratype); 8, P. ferrugineus L.; 9, P. fulvipennis Er.

This is the species listed by Fall and Cockerell in their New Mexican list as fulvipennis. In the profile of the prosternum, and characters of the female genitalia this species is intermediate between helvolus and basalis. It differs from both of them by being less oval, the prothorax black, more convex, with narrower margin, and more obtuse hind angles. The pubescence is longer and the punctation of the elytra, at least in the New Mexican specimens, more regular and distinct.

Pocadius basalis Schaeffer

Pocadius basalis Schaeffer, 1911, Journ. New York Ent. Soc., 19: 117. 
Holotype and three paratypes labelled "VIII. 29, Huach. Mts. Ariz." and one without label are in the U.S.N.M. One female from the "Huach. Mts., Ariz," is in the writer's collection and evidently was collected with the types. There is no variation in these six specimens. Niger n. sp. approaches basalis in the punctation of the elytra, but this character is very variable in helvolus and the European ferrugineus.

For the privilege of examining material the writer is greatly indebted to E. A. Chapin (U.S.N.M.), P. J. Darlington (M.C.Z.), E. C. Van Dyke (Cal. Acad. Sci.), E. T. Cresson, Jr. (Phil. Acad. Sci.), H. C. Fall, and C. A. Frost. 

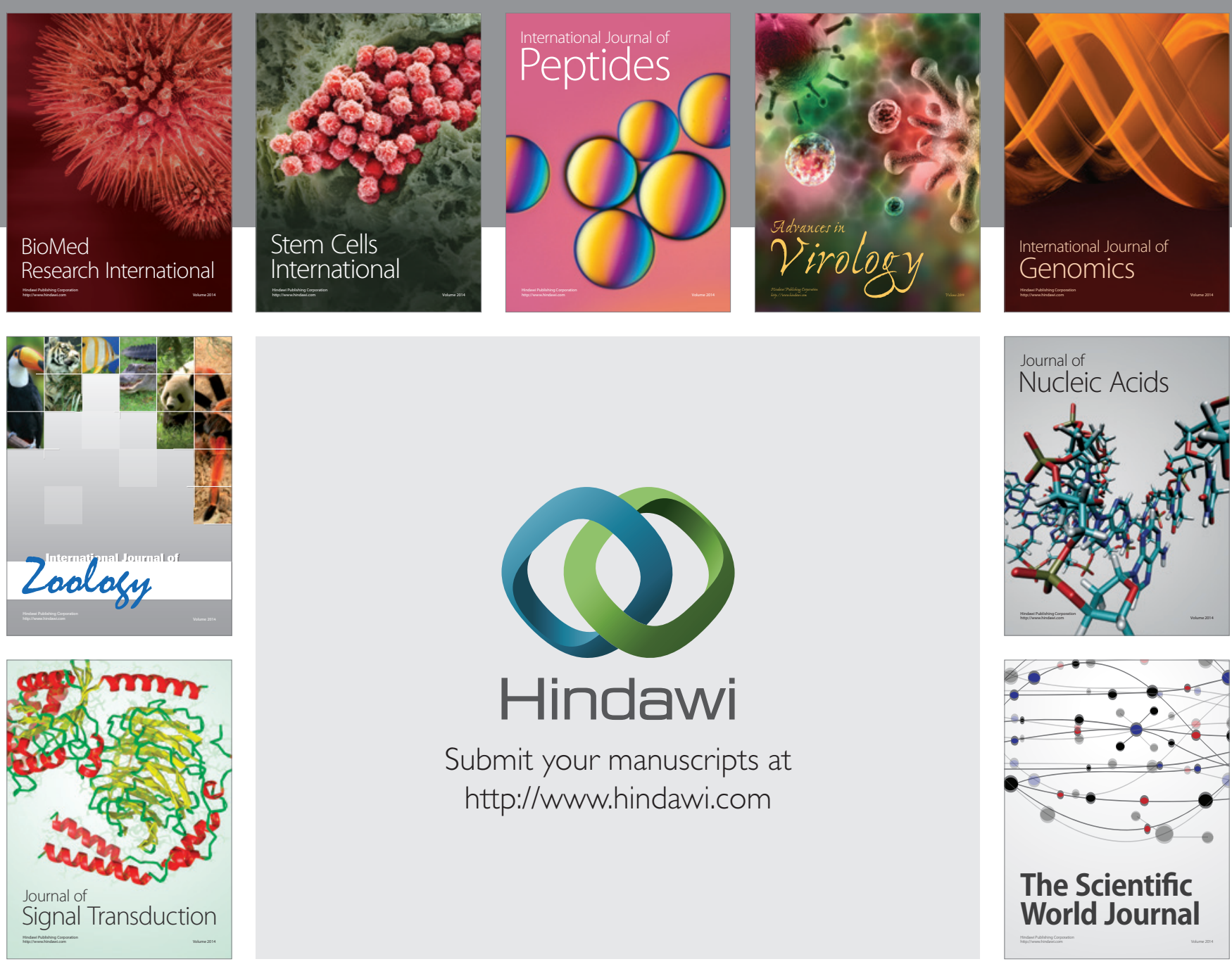

Submit your manuscripts at

http://www.hindawi.com
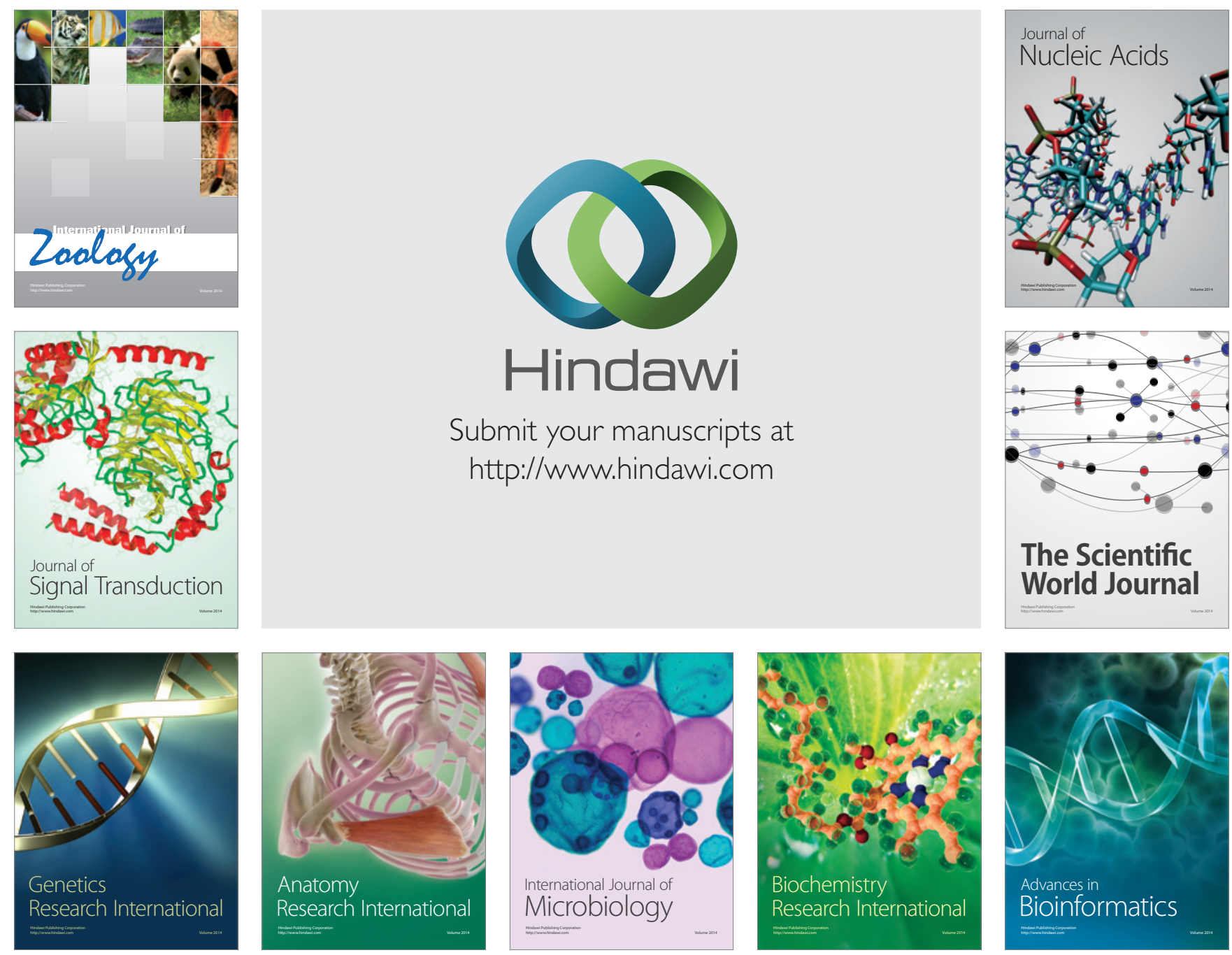

The Scientific World Journal
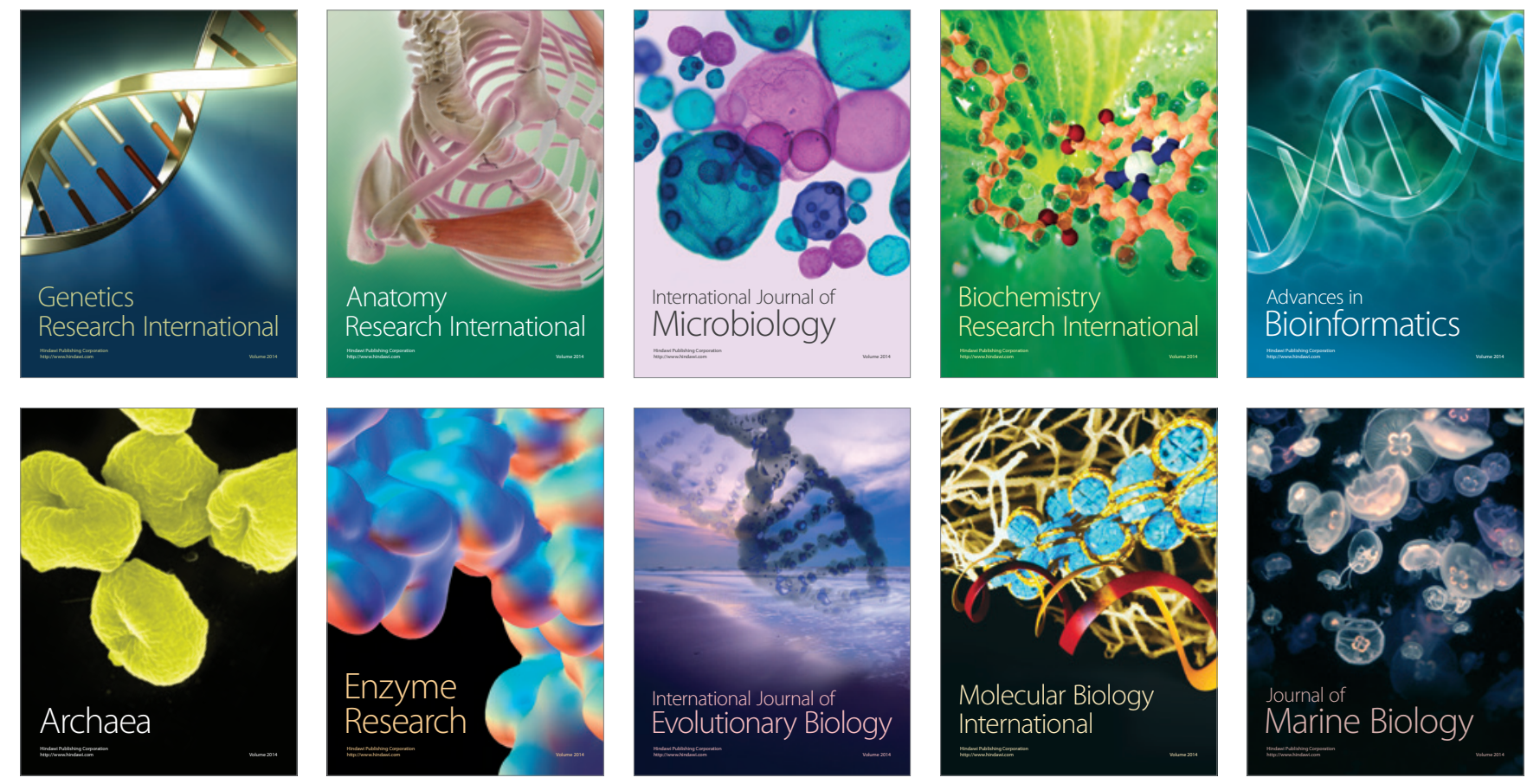